\title{
RUSSIAN FOREIGN TRADE IN FEBRUARY 2015
}

\author{
N.Volovik
}

In February 2015, Russian foreign trade continued posting the fall of main indices. Eurocommission considers that Russia remains among the leading countries which preserve different barriers that to a considerable extent hamper global trade.

In February 2015, Russian foreign trade turnover calculated on the balance of payments methodology constituted $\$ 44.7$ billion which is $26.1 \%$ less that the same index last year. At the same time, contracted total value of both exports (by $19.9 \%$ compares with 2014 index) and imports (by 35.4\%). Because of the exceeding contraction of the total value of imports in February 2015 export surplus came to $\$ 13.6$ billion which is $9.1 \%$ over and above the same index last year.

In the course of February 2015, the US dollar continued strengthening (although slower than in January) mainly due to the quantitative easing program launched by the European Central Bank (ECB). Strong dollar and slowing down of the Chinese economy (PRC GDP growth rates in Q1 2015 fell to 7\% annual - the lowest level since 2009) which remains principal consumer of raw materials in the world contribute to low prices on raw materials.

Nevertheless, price for oil changed the downward trend which originated in August 2014. Although Brent in February 2015 compared with February 2014 went down in value by $46.8 \%$ to $\$ 57.93$ per barrel but by comparison with January 2015 it appreciated by $20.5 \%$.

Price of Urals in February 2015 dropped against February 2014 by $46.7 \%$ and constituted $\$ 57.3$ per barrel. In the course of 2 first months of 2015 price of Urals contracted in comparison with the correspond- ing period of last year by $48.5 \%$ to $\$ 51.8$ per barrel. By comparison with the previous month In February price of Urals appreciated by $23.0 \%$.

According to monitoring carried out by the RF Ministry of Economic Development, from 15 March 2015 to 14 April 2015 average price of Urals constituted $\$ 53.48$ per barrel or $\$ 390.4$ per ton. As a result, crude export duty from 1 May 2015 dropped to $\$ 116.5$ per ton against $\$ 130.8$ per ton effective during previous month. Preferential export duty rate on crude from Eastern Siberia, Caspian oilfields and Prirazlomnoye oilfield will remain at the zero level from 1 May 2015 due to the new calculation formula adopted within the tax manoeuvre in the oil sector. Export duty on very heavy oil will fall to $\$ 14.7$ per ton from $\$ 16.7$ per ton. Export duty on light petroleum products and oils will constitute $\$ 55.9$ per ton (from 1 April $2015-\$ 62.7$ per ton), and on heavy petroleum products - $\$ 88.5$ per ton (\$99.4 per ton). Export duty on commercial gasoline will contract to $\$ 90.8$ per ton (from 1 April - \$102 per ton), straight-run gasoline (naphtha) - to $\$ 99.0$ per ton (\$111.1 per ton). Export duty on liquefied gas will remain at the zero level.

According to the London metal exchange, in February 2015 against January 2015 nickel prices dropped by $1.6 \%$, on copper - by $2.0 \%$, on aluminium went up by $0.7 \%$. In comparison with February 2014 price on alu-

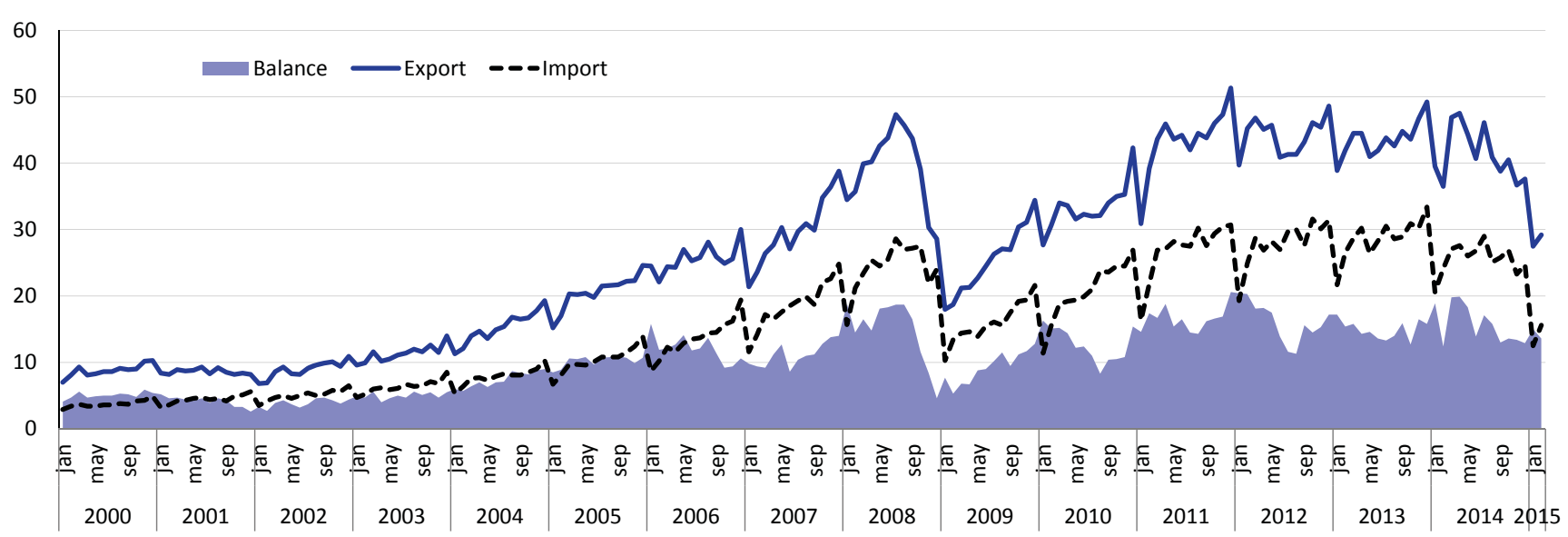

Source: $\mathrm{CB}$ of RF.

Fig. 1. Main indices of Russian foreign trade (billion US dollars) 
AVERAGE MONTHLY WORLD PRICES IN FEBRUARY OF CORRESPONDING YEAR

\begin{tabular}{|l|c|c|c|c|c|c|c|c|c|c|c|}
\hline & 2005 & 2006 & 2007 & 2008 & 2009 & 2010 & 2011 & 2012 & 2013 & 2014 & 2015 \\
\hline Brent, US\$/barr. & 44.8 & 59.7 & 58.26 & 92.66 & 43.87 & 73.8 & 104.1 & 119.7 & 116.5 & 108.81 & 57.93 \\
\hline Natural gas*, & 5.49 & 7.95 & 8.56 & 10.84 & 11.04 & 8.8 & 9.36 & 11.12 & 11.77 & 11.3 & 8.27 \\
\hline US\$/1 mn BTU & & & & & & & & & & & \\
\hline Copper, US\$/t & 3254 & 4982 & 5671.1 & 7887.7 & 3314.7 & 6899 & 9867.6 & 8441.5 & 8060.9 & 7149.2 & 5729.3 \\
\hline Aluminium, US\$/t & 1883 & 2455 & 2759.14 & 2776.9 & 1330.2 & 2061 & 2508.2 & 2207.9 & 2053.6 & 1695.2 & 1817.8 \\
\hline Nickel, US\$/t & 15350 & 14979 & 41154.5 & 27955.5 & 10409 & 19141 & 28252 & 20393.7 & 17690 & 14203.6 & 14573.8 \\
\hline
\end{tabular}

* European market, average contract price, franco border.

Source: calculated on the data released by the London Metal Exchange, Intercontinental oil exchange (London).

minium appreciated by $7.2 \%$, on nickel - by $2.6 \%$, on copper dropped by $19.9 \%$. In January-February 2015 against corresponding period of last year copper sold at $20.3 \%$ cheaper, aluminium and nickel appreciated by $6.1 \%$ and $2.4 \%$ correspondingly.

The FAO Food Price Index averaged 179.4 points in February 2015 down 1.8 points from January 2015 and 29 points (14.0\%) below its level in February 2014. In February 2015, prices on cereals, meat and especially sugar declined, however prices on vegetable oils remained unchanged. Global prices on diary products have spiked, besides this has happened for the first time since March 2014. The FAO dairy Price Index averaged 181.8 points up 8 points from January 2015. Main reason for an unexpected growth of global prices on dairy products was a decline of milk production in New Zealand provoked by drought combined with a restriction of export supplies from Australia.

In February 2015 against February 2014, export contracted practically along all main positions of an extended goods nomenclature. Export of fuel and energy complex products fell by $26.1 \%$, chemical industry - by $5.4 \%$, food - by $12.6 \%$, timber and paper - by $15.3 \%$, textiles and textile products - by $21.1 \%$, precious stones and metals - by $15.0 \%$.

Solely export of machines, equipment and means of transport went up (by 31.5\% against February 2014) as well as export of metals (by $15.3 \%$ ). Despite the fall of the world prices on metallurgical products, Russian exporters of metal increased their sales abroad and managed to grow their profit thanks to cheap ruble. For example, sales of Novolipetsky Iron and Steel Complex (biggest Russian producer of steel) in Q1 2015 against the same period last year went up by $3 \%$ to $3.96 \mathrm{~m}$ tons. At the same time, sales on foreign markets drew by $13 \%$ to $2.55 \mathrm{~m}$ tons. Their share in the overall sale portfolio increased to 64\% (59\% in Q4 2014) ${ }^{1}$.

Imports shank along all positions of goods nomenclature. Import of food products and agricultural raw materials have suffered most cuts: in comparison with

1 http://nlmk.com/docs/default-document-library/пресcрелиз-опера-ционные-результаты-группы-нлмк-за-1-квартал2015-года.pdf?sfvrsn=0
February 2014 import of foods products have declined by $40.2 \%$. At the same time, along several positions imports have increased from CIS countries. For example, import of meat (in physical terms) went up by $24.1 \%$, poultry - by $47.9 \%$, mild and cream - by $38.4 \%$, vegetable oil - three-fold.

On 19 March 2015, European commission presented fifth edition of Trade and Investment Barriers Report 20152. The Report demonstrates that the EU's strategic economic partners: China, India, Japan, Argentina, Brazil, Russia, and US continue to maintain a variety of significant trade and investment barriers which to a considerable extent hamper world trade and investment chances of EU companies.

The Report enumerates concrete barriers impeding trade on the priority for the EU markets. Russia heads the list of countries with majority of trade barriers (7), it is followed by China with 6 reported cases, followed by Brazil and India (with 4 cases each), Argentina and the US round out the list (with 3 cases each).

EU voices disagreements to the Russian Federation on the following aspects:

Russia has incorrectly implemented its WTO bound tariffs for many products, including paper, appliances and agricultural products such as palm oil. On 31 October 2014, the EU launched a request for WTO Dispute Settlement consultations.

The new Russian law on personal data localisation (Federal Law 242) signed by President Putin on 21 July 2014 requires that all personal data of Russian individuals are stored and processed in Russia, with no exemptions offered for commercial data. Such blanket local server requirements, without exemption for commercial data, are disproportionate and could have a detrimental effect on the digital economy as a whole. In particular, this creates a major barrier for European cloud providers and the development of a cross-border cloud computing market. In the EU's view, such localisation requirements should rather be limited to specific, exceptional instances (e.g. only where data security/privacy requirements cannot be ensured

2 http://trade.ec.europa.eu/doclib/docs/2015/march/tradoc_153259.pdf 
otherwise) and must be fully compatible with relevant provisions of WTO law.

Many SPS issues with Russia remain. On 8 April 2014, the EU requested WTO Dispute Settlement consultations with Russia regarding import restrictions against live 9 pigs, pork and certain pig products originating in the EU, due to the occurrence of African Swine Fever in limited areas in Lithuania and Poland close to the border with Belarus. Consultations did not bring any result and a WTO Dispute Settlement panel was established on 22 July 2014. A ban on the export of potatoes and other plants is still in place since 1 July 2013 while new issues include a ban on beef trimmings from the EU since 27 June 2014, a ban on fruits and vegetables from Poland (affecting apples in particular) introduced on 1 August 2014 and a ban on meat meals, offal and fat from the EU since 22 October 2014.

On 7 August 2014, Russia decreed a ban on agricultural products and foodstuffs from certain countries including EU Member States - which have adopted sanctions against Russia in the context of the situation in Ukraine. These products cover almost all meat products (beef meat, pig meat, poultry, and certain prepared meat products), milk and dairy products, fruits and vegetables, as well as fish and crustaceans.

In the area of Technical Barriers to Trade (TBT), EU economic operators are still facing numerous horizontal and sector-specific obstacles due to burdensome technical regulations which often establish excessive certification and conformity assessment requirements.
In many cases, technical regulations - which are now adopted by the Eurasian Economic Union - are incompatible with international standards. Important examples of overly burdensome technical regulations established by the Eurasian Economic Union are the technical regulation on safety of consumer goods and goods destined for children and adolescents (amongst others relevant for textiles, clothing and footwear) as well as the draft technical regulation on alcoholic product safety.

Russia has adopted a subsidy programme that includes subsidies to the producers of farm equipment and agricultural machinery. This programme establishes subsidies for manufacturers and purchasers of agricultural machinery under certain local content conditions. This is detrimental for EU exporters of agricultural machinery (in particular of combine harvesters) which have a strong interest in the Russian market.

On 14 May 2013, the Eurasian Economic Commission imposed anti-dumping duties on imports of light commercial vehicles from Germany and Italy. As a consequence of the measure, exports of light commercial vehicles from the EU to Russia virtually stopped because of the prohibitive duty level. The anti-dumping measures are to be applied for 5 years and affect approx. 180 million $€$ of EU exports. Several EU companies have seen their market presence dramatically reduced in this market segment in Russia. The Commission launched WTO Dispute Settlement proceedings and a panel was established on 20 October 2014. 